The General Election of 2011 in the Republic of Ireland: All Changed Utterly?

Little, Conor

Published in:

West European Politics

DOI:

$10.1080 / 01402382.2011 .616669$

Publication date:

2011

Citation for published version (APA):

Little, C. (2011). The General Election of 2011 in the Republic of Ireland: All Changed Utterly? West European Politics, 34(6), 1304-1313. https://doi.org/10.1080/01402382.2011.616669 


\section{The general election of 2011 in the Republic of Ireland: all changed utterly?}

Word count: 4,230

Conor Little, European University Institute

Email: Conor.Little@eui.eu

This is an Accepted Manuscript of an article published by Taylor \& Francis in West European Politics on 1 November 2011, available online:

http://www.tandfonline.com/doi/full/10.1080/01402382.2011.616669

Full citation: Little, C. 2011. 'The general election of 2011 in the Republic of Ireland: all changed utterly?', West European Politics 34 (6): 1304-1313.

\section{Acknowledgement}

I would like to acknowledge the contribution of the late Professor Peter Mair (1951-2011) to this election review article, both as Editor of West European Politics and as this author's mentor at the European University Institute. 
On 9 March 2011, the $31^{\text {st }}$ Dáil (the lower house of the Irish parliament) convened for the first time and elected Enda Kenny of Fine Gael as Taoiseach (prime minister) by 117 votes to 27. Breaking with tradition, a depleted Fianna Fáil party did not propose an alternative candidate and abstained from the vote. Kenny's election brought to an end Fianna Fáil's fourteen consecutive years in Cabinet on the back of three successful elections in 1997, 2002 and 2007. It reshaped a political system that Fianna Fáil had previously dominated for more than half a century, holding an apparently permanent plurality of votes and parliamentary seats since 1932 and spending more than 61 of the past 79 years in government. ${ }^{i}$

The governing parties sustained extremely heavy losses. Fianna Fáil held onto only a quarter of the seats that it won in the 2007 general election and the Green Party, after almost twenty-two years in parliament, lost all of its six seats. Fine Gael came closer to an overall majority than at any time since the 1920 s, winning more than $45 \%$ of the 166 Dáil seats. The Labour Party won more seats than ever before and became the second-largest party in the Dáil for the first time since Fianna Fáil entered parliament in 1927. Sinn Féin, after false dawns in 2002 and 2007, made an electoral breakthrough, more than tripling the number of seats that it won in 2007. Minor left-wing parties achieved small, and for them unprecedented successes and non-party candidates ('Independents') of various persuasions were more numerous than at any time since the 1920 s. However, the story was not simply one of change: the Irish party system, a product of Civil War divisions in the early 1920s, withstood this electoral earthquake remarkably well, and in many respects the new Dáil and Cabinet were similar to their predecessors.

\section{A contracting economy and a crumbling majority}

Brian Cowen succeeded Bertie Ahern as Taoiseach on 7 May 2008. Upon the termination of Cowen's tenure, he had held that office for the lowest cumulative number of days (1036) of any of his predecessors in Fianna Fáil. As in 2002 and 2007, the economy was a central theme in the 2011 
election. However, Cowen's tenure of less than three years was arguably one of the most eventful in Irish history, making the economic and political context nigh unrecognisable from that of the previous election.

By polling day, the government had overseen unprecedented economic and financial decline. GDP growth of over $5 \%$ up to the end of 2007 was followed by rapid contraction of $3 \%$ in 2008 ; $7 \%$ in 2009 ; and $0.4 \%$ in 2010 . GNP declined by $2.8 \%$ in $2008,10 \%$ in 2009 ; and recovered slightly - by $0.3 \%$ - in 2010 . The rate of unemployment, which had consistently been less than $5 \%$ until early 2008, reached almost 15\% in December 2010 (Central Statistics Office 2011). By the end of 2010, government debt was approaching 100\% of GDP, up from 25\% in 2007 (Eurostat 2011).

That the Irish economic crisis was quite clearly attributable to policy failures compounded the government's problems. From 1997, governments followed procyclical policies that were designed to win elections and, in 2002 and 2007 they did, providing "effective political messages for the electorate, but not good tax policy" (Independent Review Panel 2011: 32). These policies contributed to a property bubble and a narrow tax base that was excessively dependent on property transactions. By February 2011, residential property prices had fallen by about $40 \%$ in four years (Central Statistics Office 2011). The second policy failure concerned the regulation of Irish banks. This allowed unsustainable lending practices which culminated, in September 2008, in rumours of the impending collapse of Anglo Irish Bank, which would have been followed by the other Irish banks. In response, the government, supported in parliament by Fine Gael and Sinn Féin, guaranteed Irish banks' liabilities worth approximately $€ 485$ billion, including deposits and bonds. This effectively committed the government to providing ongoing support for the banks, which took the form of recapitalisation, the nationalisation of loans worth $€ 77$ billion, and state investment in the banks up to and including full nationalisation.

The government's response to this crisis, focussing mainly on spending cuts, exacerbated its electoral difficulties, which were clearly apparent in the local and European Parliament elections of 
June 2009 (see Quinlivan and Weeks 2010; Quinlan 2010; Little et al 2010), and precipitated important changes in its parliamentary support (see Took and Donnelly 2011). Two Fianna Fáil TDs (Joe Behan and Dr. Jim McDaid) refused to support government cutbacks and left Fianna Fáil (one immediately, the other two years later); an Independent TD (Finian McGrath) withdrew his support for the government for the same reason; and, a month before the election, a Fianna Fáil TD (Mattie McGrath) left the party (and was duly re-elected). Fianna Fáil suffered other losses after Minister Séamus Brennan died in July 2008; Pat 'The Cope' Gallagher won a seat in the European Parliament in June 2009; and Minister Martin Cullen announced his resignation in March 2010, citing a medical condition. The by-election to replace Gallagher took place in November 2010, but only after the Sinn Féin candidate and eventual winner, Senator Pearse Doherty, took legal action that led the High Court to deem as unconstitutional the long delay in holding the election.

The main opposition party, Fine Gael, was not without its own travails. In June 2010, following the acrimonious resignation from both Fine Gael and the parliament of new and popular Fine Gael TD George Lee, poor opinion poll ratings and an obvious lack of confidence in Enda Kenny's leadership among Fine Gael TDs, the party's Finance Spokesperson Richard Bruton and his supporters attempted to replace him as leader. Kenny's campaign within the parliamentary party saw off Bruton's challenge. In the reshuffle that followed, he sidelined his main antagonists and promoted to the position of Finance Spokesperson former party leader Michael Noonan, whose position he had taken in 2002.

\section{The bailout}

Political turbulence intensified in late 2010 and early 2011, eventually leading to the collapse of the government coalition. This occurred in two main episodes. The first, in November 2010, resulted in Ireland taking a multilateral loan worth $€ 67.5$ billion $^{\mathrm{ii}}$ and the Green Party announcing that it intended to leave government in early 2011, upon the completion of the Budgetary process. The 
second episode, in January 2011, resulted in Fianna Fáil replacing Brian Cowen as party leader, the Green Party's abrupt departure from Cabinet, the main opposition parties cooperating with the government to finalise the Budgetary process, and, finally, the setting of a date for the general election.

The multilateral loan that was agreed on 28 November and accompanied by a four-year austerity plan, was most proximately a result of increased pressure from the European Central Bank (ECB), from mid-November, to take a 'bailout', as Ireland was effectively excluded from international bond markets (O'Brien 2011). The ECB, supported by the US and by EU member states, who were concerned for their investors, appear to have opposed an International Monetary Fund (IMF) proposal that Ireland reduce its liabilities by defaulting on some bank bonds (Kelly 2011). For several days, senior government ministers flatly denied that Ireland needed aid and that there were negotiations occurring. Rumours of impending bank runs prompted an extraordinary intervention on 18 November when, without consulting the government, the Governor of the Central Bank of Ireland telephoned a morning radio programme from Frankfurt and became the first Irish official to confirm that Ireland would take a loan amounting to "tens of billions" and that the IMF, European Commission and ECB negotiating teams were already in Dublin. On 22 November, the Green Party announced that that it wanted an election by the end of January and that it would withdraw from government upon the completion of the Budgetary process.

In the new year, Brian Cowen defeated a leadership challenge by his Foreign Minister, Micheál Martin. He then asked five ministers who were not standing for re-election to resign, with a view to giving election candidates the visibility afforded by promotion. The Green Party refused to support the appointment of new ministers to these positions, and the Taoiseach was forced to reassign the vacant ministries to sitting ministers.

The unpopularity of the attempted reshuffle and the obviously poor political management behind it put the already-weak party leader in an untenable position. On 22 January, Brian Cowen announced 
that he was resigning as leader of Fianna Fáil, but would remain as Taoiseach. The Green Party left the government the following day, citing Fianna Fáil's failure to resolve doubts about its leadership, and a lack of communication and a breakdown of trust between the parties. Fine Gael and Labour facilitated the finalisation of the coalition's Budgetary process by deferring motions of no confidence in the Taoiseach and the government. Micheál Martin was elected as leader of Fianna Fáil on 26 January. Brian Cowen confirmed that he would not contest the election, becoming the first Taoiseach to hold office during a general election but not to win a seat (or indeed to stand) in that election. On 1 February, the Taoiseach advised the President, Mary McAleese, to dissolve the Dáil and to summon a new Dáil on 9 March. ${ }^{\text {iii }}$ The election was called for Friday 25 February.

\section{The campaign}

Fianna Fáil and the Green Party were on the back foot for the duration of the campaign. Opinion polls in early 2011 consistently indicated that Fianna Fáil had the support of less than (and sometimes considerably less than) $20 \%$ of respondents, compared to almost $42 \%$ of the vote in 2007. Candidate selection strategy became the focus of several intra-party rows at constituency level within Fianna Fáil. This included conflicts between ministers Mary Hanifin and Barry Andrews (both of whom lost their seats) and between putative candidates in the Taoiseach's constituency of Laois-Offaly.

In the expectation that the government would fall early, the opposition parties had effectively been pursuing their campaigns for some time. Fine Gael ran a simulated campaign as far back as November 2009 (McGee 2011b). Parties and candidates invested considerable time and resources in developing their social media presence, and by polling day, 148,000 Twitter accounts were 'following' 326 candidates (Healy 2011). The substance of the parties' campaign communications strategies were showcased in four televised party leaders' debates during the campaign: one threeway debate in the Irish language; one two-way debate between Labour and Fianna Fáil ${ }^{\text {iv }}$; and two 
further five- and three-way debates. During these debates and other media appearances, the Fine Gael leader relentlessly repeated that he had a "five point plan to get Ireland working". While this provided fodder for satirists, it is widely accepted as having been an effective tactic.

The involvement of the leader of the Labour Party, Eamon Gilmore, in all of the televised leaders' debates was a new departure and marked the extent to which opinion poll ratings and the local and European elections of 2009 had established their position as Ireland's second party. Labour's communications strategy relied on being in a position to challenge for the position of largest party, using the 'Gilmore for Taoiseach' slogan. When the party's opinion poll ratings began to wane during the campaign, the slogan appeared incongruous. A second, more familiar strand to their strategy relied on distinguishing Labour's policies from orthodox responses to the economic crisis. Gilmore claimed that it was "Frankfurt's way or Labour's way" and described Fianna Fáil and Fine Gael as a "Celtic Tory consensus".

The central policy issue in the election campaign was the terms of Ireland's multilateral loan, most especially the interest rate which, at $5.8 \%$, was viewed as punitive. Spokespersons for Labour and Fine Gael suggested that they would reduce the interest rate to 3 or $3.5 \%$ in the face of a flat denial by the ECB that this would be considered (Prime Time 2011). Fine Gael placed particular emphasis on Enda Kenny's relationship with Chancellor Angela Merkel: their campaign included a meeting between Kenny and Merkel in Berlin. Fianna Fáil insisted that the terms of the loan represented the best deal that could be negotiated, while Sinn Féin suggested that it would not draw down further on the loan and that Ireland should default on bank bonds.

\section{Result}

When counting ended on 2 March at $8.15 \mathrm{am}$, turnout was almost 3\% higher than 2007, at $69.9 \%$. In aggregate partisan terms, the election was the most volatile in Irish history and the third-most volatile in Western Europe since 1945 (Mair 2011). The Fine Gael leader described the outcome as 
a "revolution at the ballot box", as did senior members of the Labour Party (Finlay 2011).

Table 1. The February 2011 and May 2007 election results.

\begin{tabular}{|c|c|c|c|c|c|c|}
\hline & \multicolumn{3}{|c|}{2007} & \multicolumn{3}{|c|}{2011} \\
\hline & $\%$ votes & Seats & $\%$ seats & $\%$ votes & Seats & $\%$ seats \\
\hline Fine Gael & 27.3 & 51 & 30.7 & 36.1 & 76 & 45.8 \\
\hline Labour Party & 10.1 & 20 & 12.0 & 19.5 & 37 & 22.3 \\
\hline Fianna Fáil & 41.6 & 78 & 47.0 & 17.4 & 20 & 12.0 \\
\hline Sinn Féin & 6.9 & 4 & 2.4 & 9.9 & 14 & 8.4 \\
\hline Socialist Party & 0.6 & 0 & 0.0 & 1.2 & 2 & 1.2 \\
\hline People before Profit Alliance & 0.5 & 0 & 0.0 & 1.0 & 2 & 1.2 \\
\hline Green Party & 4.7 & 6 & 3.6 & 1.9 & 0 & 0.0 \\
\hline Progressive Democrats & 2.7 & 2 & 1.2 & $\mathrm{n} / \mathrm{a}$ & $\mathrm{n} / \mathrm{a}$ & $\mathrm{n} / \mathrm{a}$ \\
\hline Non-party ('Independents') & 5.8 & 5 & 3.0 & 12.6 & 15 & 9.0 \\
\hline Totals* & 100.2 & 166 & 99.9 & 99.6 & 166 & 99.9 \\
\hline Turnout & 67.03 & & & 69.9 & & \\
\hline \multicolumn{7}{|c|}{$\begin{array}{l}\text { n/a = not applicable. The Progressive Democrats were dissolved in November 2009, with its TDs becoming Independents. } \\
{ }^{\star} \text { Rounding error and the exclusion of very small parties cause these totals to be greater or less than } 100 . \\
\star * \text { Fianna Fáil held the office of Ceann Comhairle (speaker of the house) at both elections. This office-holder is returned aut }\end{array}$} \\
\hline
\end{tabular}

It was the first time since the 1930s that Fianna Fáil was not the largest party in the Dáil, that its vote fell below $39 \%$, or that it had attained a lower proportion of seats than votes. The party also failed to win a plurality of first-preference votes in any constituency (compared to 32 out of 43 in 2007) and, in Dublin, they lost all but one of their seats. ${ }^{\mathrm{v}}$ The Green Party lost all of its seats and, by failing to attain $2 \%$ of first-preference votes, lost its entitlement to state funding. Party leader John Gormley summarised the causes of the party's defeat as follows: "One. We were in government. Two. We were in government with Fianna Fáil. Three. We were in government with Fianna Fáil during the worst recession in the State. It made our challenge insurmountable" (McGee 2011a).

Fine Gael won a plurality of the vote in all but ten constituencies and an unprecedented four out of five seats in Enda Kenny's home constituency of Mayo. Labour became the largest party in Dublin. The winning parties were relatively successful at converting votes into seats. Despite exceeding their share of the vote in the 1992 'Spring Tide' by just $0.09 \%$, the Labour Party won four more seats than in that earlier election, and while Fine Gael did not reach its historical maximum vote 
share (42\% in 1982), it nevertheless won six more seats than it did at that time (Ryan 2011).

Despite the apparent demand for change, only two parties that had not been in the previous parliament won representation, together accounting for four seats, and only one of these - the People Before Profit Alliance - entered the Dáil for the first time. Non-party candidates clearly profited from the electorate's discontent and fifteen Independents were returned. Some of the more notable were Mick Wallace, a long-haired, leftist developer; Luke 'Ming' Flanagan, a long-time cannabis-decriminalisation campaigner; and Shane Ross, a conservative former stockbroker. Together, the two smallest parliamentary parties and twelve Independents established an eclectic 'technical group' in order to maximise their speaking rights in parliament. Three Independents Michael Lowry, Noel Grealish and Michael Healy-Rae - did not join the group. Within weeks of the election, Lowry, a long-time TD and former Fine Gael Communications Minister, was found by a judicial tribunal to have had a "disgraceful" and "insidious" role in assisting businessman Denis O'Brien to attain a mobile phone license in 1995 and to have been involved in a "profoundly corrupt" attempt to enrich another businessman, Ben Dunne, by seeking to influence decisions in his favour (Moriarty Tribunal 2011).

Volatility was not restricted to parties' electoral shares. At the level of individual parliamentarians, there was considerable turnover. More than half of the TDs returned to the $31^{\text {st }}$ Dáil -76 first-time TDs and eight former-TDs - had not been members of the previous parliament. Of these 84 'new' TDs, only three represented Fianna Fáil. A record number of sitting TDs (36) did not contest the election, including 21 from Fianna Fáil (McCarthy ed. 2011, p.63), while 45 of the 127 outgoing TDs who contested the election lost their seats, of whom 36 were Fianna Fáil or former-Fianna Fáil TDs. These 81 resignations and defeats drew considerable attention to the generous pensions and other entitlements available to TDs and ministers upon retirement.

Despite its volatility, the election was also marked by continuity. Only twenty-five women were elected, compared to 23 in 2007. The average age of TDs dropped for the first time since 1982, but 
only slightly, from 50.4 years in June 2007 to 48.5 in March 2011 (Farrelly 2011). Family dynasties were ruptured, but others continued, with success for Brian Cowen's brother Barry, for a former Labour Party leader's nephew, Arthur Spring, and for the new Taoiseach whose father had held a seat in Mayo from 1954.

\section{Government formation}

Fine Gael's strong performance unexpectedly opened up the possibility of a single-party minority government, supported by like-minded Independents and tolerated by others. However, the outcome was in little doubt: Fine Gael's preference, with unpalatable policy decisions on the horizon, was for a coalition that involved its largest electoral competitor and Labour's preference was to go into government, rather than being the largest party in opposition. Following negotiations that were punctuated by well-publicised briefings on the state of the economy, the government programme was agreed on 5 March. It was approved by a Labour Party conference of approximately 1,000 delegates from local party branches, including a trade union block. The programme was discussed, but not voted on, by a meeting of the Fine Gael parliamentary party. For the first time, the two largest parties in the Dáil formed a government coalition.

On the afternoon of his election as Taoiseach, Enda Kenny appointed his Cabinet and two junior ministers who would sit, but not vote, at Cabinet. Fine Gael received ten senior Cabinet positions, while Labour received five, including the position of Tánaiste (deputy prime minister). Senior positions, such as Minister for Finance and politically attractive positions, such as Minister for the Environment, Community and Local Government, were allocated to those who supported Enda Kenny's leadership in June 2010. Later that week, the new Taoiseach brought the total number of junior ministers to fifteen, despite the publication of a Fine Gael Bill in April 2009 that would have legislated for a maximum of twelve such positions.

Only two women were appointed to the Cabinet. There was considerable tension within the Labour 
Party as Joan Burton, who had served as Deputy Leader and Finance Spokesperson since 2002, was overlooked for a high-ranking economic ministry, receiving instead the position of Minister for Social Protection. The allocation of the new Department of Children to Frances Fitzgerald also became controversial after one Labour Party minister defended the appointment by saying that: "Women know more about children than men, because they spend more time with them".

The most important test of political change will ultimately be in the domain of policy. In its first 100 days, the new Government announced some important policy changes, including political reforms (gender quotas for candidate selection and a referendum on the abolition of the Seanad [upper house] in 2012); undoing planning regulations introduced by the previous government; and restoring the minimum hourly wage to $€ 8.65$. Other new policies, such as the introduction of water charges and a property tax, were effectively part of the government's agreement with the EU and IMF. However, the government's policies on central campaign issues were, within its first 100 days, marked by continuity: it continued to recapitalise and invest in Irish banks; it did not impose losses on bank bondholders; it did not attain a reduction in the interest rate on the remaining multilateral $\operatorname{loan}^{\mathrm{vi}}$; and it insisted that it would retain a corporate tax rate of 12.5\%. Opinion polls in June 2011 indicated that its popularity remained high.

\section{Electoral change and political continuity?}

The changes wrought by the election of February 2011 were historic and dramatic. Irish voters shaped a much-altered playing pitch upon which the parties will compete at the next general election. However, they chose to do so while staying within the parameters of a party system and a political culture that has long been particular to Ireland. The new Dáil and Cabinet looks a lot like the old one: male and middle-aged. There is still no far right party in Ireland (see O'Malley 2008) and far left parties remain marginal. Seventy-three percent of voters voted for the three main parties in 2011, compared to $79 \%$ in 2007; and much of this decline might be illusory, being attributable to 
the increased success of Independents, some of whom have links to these parties, and Sinn Féin, which like Fine Gael and Fianna Fáil, has its origins in nationalist concerns.

Bartolini and Mair (1990, pp. 70-72) observed that highly volatile elections in Western Europe are usually followed by further electoral volatility, and that this is generally accounted for by continued change, rather than a restoration of the past partisan order. In Ireland, a reversion to a variant of the pre-2011 party system remains possible, if Fianna Fáil reasserts itself on the back of further antiincumbent voting, and if new parties fail to emerge. However, this is far from certain and it may depend on Ireland's economic fate. Two months into the new government's term, economist Morgan Kelly (2011) speculated on the electoral implications of possible - in his view inevitable - national bankruptcy:

"The destruction wrought by the bankruptcy will not just be economic but political. Just as the Lenihan bailout destroyed Fianna Fáil, so the Noonan bankruptcy will destroy Fine Gael and Labour, leaving them as reviled and mistrusted as their predecessors. And that will leave Ireland in the interesting situation where the economic crisis has chewed up and spat out all of the State's constitutional parties. The last election was reassuringly dull and predictable but the next, after the trauma and chaos of the bankruptcy, will be anything but."

Ireland's political past, through parties, traditions and institutions, continues to structure the system in 2011, just as it has done since the 1920s; whether events in coming months and years will cause a definitive break with that past is now, more than ever, an open question.

\section{Bibliography}

Allern, Elin Haugsgjerd (2010). 'Survival of a Majority Coalition: The Norwegian Parliamentary Election of 14 September 2009'. West European Politics 33:4, 904-912. 
Central Statistics Office (2011). http://www.cso.ie/. Last accessed 28 June 2011.

Dinas, Elias (2010). 'The Greek General Election of 2009: Pasok - The Third Generation.' West European Politics 33:2, 389-398.

Eurostat (2011). http://epp.eurostat.ec.europa.eu/portal/page/portal/eurostat/home/. Last accessed 28 June 2011.

Farrelly, Mark (2011). 'Election 2011 - an age old story? An age profile of the $31^{\text {st }}$ Dail.' Posted to politicalreform.ie on 31 March 2011. URL: http://politicalreform.ie/2011/03/31/election-2011-anage-old-story-an-age-profile-of-the-31st-dail/\#more-2495. Last accessed 28 June 2011.

Faas, Thorsten (2010). 'The German Federal Election of 2009: Sprouting Coalitions, Drooping Social Democrats.' West European Politics 33:4, 894-903.

Finlay, Fergus (2011). 'Voters stage their historic revolution at the ballot box.' Irish Examiner, 28 February 2011. URL: http://irishexaminer.ie/archives/2011/0228/ireland/voters-stage-theirhistoric-revolution-at-the-ballot-box-146660.html. Last accessed 28 June 2011.

Healy, Blathnaid (2011). 'Defeat by Tweet.' In McCarthy, Deirdre. ed. 2011. Election 2011 \& the $31^{\text {st }}$ Dáil. Dublin: RTÉ.

Independent Review Panel (2011). 'Strengthening the capacity of the Department of Finance. Report of the Independent Review Panel.' December 2010.

Kelly, Morgan (2011). 'Ireland's future depends on breaking free from bailout'. The Irish Times. 7 May 2011. URL: http://www.irishtimes.com/newspaper/opinion/2011/0507/1224296372123.html

Lisi, Marco. (2010). 'The Renewal of the Socialist Majority: the 2009 Legislative Elections'. West European Politics 33(2): 381-388

Little, Conor., Sudulich, Maria Laura. \& Wall, Matt (2010). 'Ireland.' In W. Gagatek, ed. The 2009 Elections to the European Parliament: country reports. Florence: European University Institute.

Mair, Peter (2011). 'One of Europe's most volatile elections.' Posted to politicalreform.ie on 28 February 2011. URL: http://politicalreform.ie/2011/02/28/one-of-europe\%E2\%80\%99s-mostvolatile-elections/. Last accessed 28 June 2011.

McCarthy, Deirdre. ed. (2011). Election 2011 \& the $31^{\text {st }}$ Dáil. Dublin: RTÉ.

McGee, Harry. (2011a). 'And then there were none: can Greens rise from ashes?' The Irish Times, 25 March 2011. URL: http://www.irishtimes.com/newspaper/opinion/2011/0325/1224293044453.html Last accessed 28 June 2011.

McGee, Harry (2011b). 'When Harry met Enda, Micheál and Eamon.' The Irish Times Election 2011 podcast. Uploaded on URL: http://audioboo.fm/boos/286751-audio-the-irish-times-election-2011when-harry-met-enda-micheal-and-eamon Last accessed 28 June 2011.

Moriarty Tribunal (2011). Report of the Tribunal of Inquiry into Payments to Politicians and Related Matters. Part II.

O'Brien, Dan (2011). 'Bailout Boys go to Dublin.' First broadcast on 24 April 2011 on BBC Radio 4. URL: http://www.bbc.co.uk/programmes/b010mryv\#broadcasts. Last accessed 28 June 2011.

O'Malley, Eoin (2008). Why is there no Radical Right Party in Ireland? West European Politics, 31(5), pp.960-977.

Prime Time (2011). 'Achtung Euro'. First broadcast on RTÉ 1 on 27 January 2011.

Quinlan, Stephen (2010). 'The 2009 European Parliament Election in Ireland.' Irish Political 
Studies, 25(2), pp.289-301.

Quinlivan, Aodh \& Weeks, Liam (2010). 'The 2009 Local Elections in the Republic of Ireland.' Irish Political Studies, 25(2), pp.315-324.

Took, Christopher \& Donnelly, Seán (2011). Elections Ireland. URL: http://electionsireland.org/. Last accessed 28 June 2011.

${ }^{\mathrm{i}}$ For other recent reports in this elections in context series, see Allern (2010), Dinas (2010), Fass (2010) and Lisi (2010).

${ }^{\text {ii }}$ Contributors to the loan were the European Financial Stability Mechanism ( $\left.€ 22.5 \mathrm{bn}\right)$; the International Monetary Fund ( $€ 22.5 \mathrm{bn})$; the European Financial Stability Fund ( $€ 17.7 \mathrm{bn})$; and the UK, Denmark and Sweden (€4.8bn).

iii This formulation is derived from Article 13.2.1 of the Irish Constitution, Bunreacht na hÉireann. In principle, the President can refuse to dissolve the Dáil.

${ }^{\text {iv }}$ The Fine Gael leader refused to participate in this debate, which was to have been a three-way debate, first citing offence caused in the past by the proposed moderator and then (when the moderator offered to step aside) a clash with his schedule.

${ }^{\mathrm{v}}$ The holder of that seat, former Minister for Finance Brian Lenihan Jnr., passed away soon after the election, on 10 June 2011.

${ }^{v i}$ However, the parties to the multilateral loan did decide to reduce the interest rate soon thereafter, in July and in September 2011. 